\title{
PENGARUH EDUKASI TERHADAP PENAMBAHAN BERAT BADAN DIANTARA DUA WAKTU DIALISIS PADA PASIEN HEMODIALISIS DI RSUD KOTA TASIKMALAYA
}

\author{
Ida Rosdiana ${ }^{1}$, Yanti Cahyati ${ }^{2}$ \\ 1,2. Dosen Jurusan Keperawatan Poltekkes Kemenkes Tasikmalaya,
}

\begin{abstract}
Abstrak
Penambahan berat badan diantara dua waktu dialisis merupakan salah satu masalah yang sering dialami pasien gagal ginjal kronik yang menjalani hemodialisis, yang jika berada pada angka diatas $5 \%$ dapat menyebabkan beberapa komplikasi yang serius. Salah satu penyebab masalah tersebut adalah karena ketidakmampuan pasien dalam melakukan perawatan diri (self care), sehingga diperlukan suatu tindakan educative supportive keperawatan. Penelitian bertujuan untuk menjelaskan pengaruh edukasi terhadap penambahan berat badan diantara dua waktu dialisis. Desain penelitian menggunakan metode quasi experiment, dengan rancangan pretest and post test group tanpa kelompok kontrol. Jumlah sampel 34 responden dengan teknik pengambilan sampel adalah purposive sampling. Responden diberikan edukasi sebanyak 3 sesi dengan materi yang berbeda pada setiap sesinya dan dilakukan observasi berat badan selama dua minggu setelah sesi edukasi berakhir. Hasil penelitian menunjukkan ada perbedaan yang signifikan rata-rata penambahan berat badan diantara dua waktu dialisis antara sebelum dan setelah dilakukan edukasi $(p$-value $=0,0001)$. Penelitian ini merekomendasikan perlunya penelitian lebih lanjut dan pemberian edukasi secara terprogram kepada pasien hemodialisis.
\end{abstract}

Kata kunci: hemodiaisis; IDWG (penambahan BB diantara 2 waktu dialisis); edukasi

\begin{abstract}
Interdialysis weight gain (IDWG) is one of many problems faced by haemodialysis patients around the world. This IDWG would give many serious complications if equal or more than $5 \%$ from patient's dry weight. One of many causes is patients self care deficit, that need educativesupportive nursing. This study was conduct to analyze the effect of education programme in IDWG. The design was quasi experiment with pre-test and post test group without control group. Purposive sampling technique was employed in sample selection and 34 patients participate in this study. Education was accommodate in three session and the weight gain were observed through the next two weeks. The results determine that self education gave effect to the IDWGs $(p=0,0001)$. The study recommends further research and education provision are programmed to hemodialysis patients.
\end{abstract}

Key Words: haemodyalisis; Interdialysis weight gain (IDWG), education

\section{PENDAHULUAN}

Pasien gagal ginjal tahap akhir atau ESRD akan mengalami kehilangan fungsi ginjalnya sampai $90 \%$ atau lebih, sehingga kemampuan tubuh untuk mempertahankan keseimbangan cairan dan elektrolit terganggu, fungsi ekskresi menjadi tidak adekuat, fungsi hormonal terganggu serta terjadinya kondisi uremia atau azotemia
(Parson, et al, 2006; Johnson, 2008). Kondisi tersebut menyebabkan penderita gagal ginjal kronik harus menghadapi terapi pengganti ginjal. Salah satu terapi pengganti ginjal yang saat ini paling banyak dilakukan dan jumlahnya terus meningkat dari tahun ke tahun adalah hemodialisis. 
Masalah yang paling sering dihadapi pasien adalah penambahan berat badan diantara dua waktu hemodialisis (interdialysis weight gain= IDWG) yang pada dasarnya disebabkan oleh ketidakmampuan fungsi ekskresi ginjal, sehingga berapapun jumlah cairan yang diasup pasien, penambahan berat badan akan selalu ada. Dengan kata lain penambahan berat badan sebanyak nol $\mathrm{ml}$ tidak mungkin terjadi. Penambahan nilai IDWG yang terlalu tinggi dapat menyebabkan hipotensi, kram otot, hipertensi, sesak nafas, mual dan muntah, dan lainnya yang dapat memperburuk kondisi pasien. Penambahan IDWG seringkali disebabkan karena tidak adanya perilaku self-care pasien akibat tidak patuh terhadap program edukasi yang diberikan (Barnett (2008) dan Valdez (2003) dalam White, 2004). Lebih dari $50 \%$ pasien hemodialisis tidak memiliki perilaku self-care (Kuther (2001, dalam White, 2004).

\section{METODE}

Desain penelitian yang digunakan adalah pra eksperimental dengan pendekatan one group pretest-posttest. Jumlah sampel penelitian 30 responden dengan teknik pengambilan sampel purposive sampling. Penelitian dilakukan di Unit Hemodialisis RSUD Kota Tasikmalaya pada bulan september sampai dengan oktober 2013.

Alat pengumpulan data yang digunakanan adalah lembar isian, lembar observasi dan timbangan berat badan. Dalam proses pengumpulan data peneliti dibantu oleh asisten peneliti yang merupakan perawat rumah sakit dengan
Di RSUD Kota Tasikmalaya, dalam bulan Maret 2012, tercatat lebih dari 30\% pasien memiliki penambahan berat badan diantara dua waktu dialisis $\geq 5 \%$ yang menyebabkan mereka berada pada keadaan beresiko terkena komplikasi kelebihan cairan (overfluid). Edukasi mengenai komplikasi penambahan berat badan pernah diberikan oleh perawat Unit Hemodialisis, namun tidak menggunakan panduan khusus tertentu dalam melakukan edukasi sehingga evaluasi mengenai kemampuan mandiri pasien tidak dapat dilakukan.

Uraian ringkas pada latar belakang diatas memberikan dasar bagi peneliti untuk merumuskan pertanyaan penelitian sebagai berikut "Apakah terdapat pengaruh edukasi terhadap penambahan berat badan diantara dua waktu dialisis pada pasien hemodialisis di Rumah Sakit Umum Daerah Kota Tasikmalaya?"

pendidikan akhir D3 Keperawatan yang memiliki ketrampilan dan kemampuan dalam melakukan observasi penambahan berat badan sebanyak dua orang.

Analisis yang digunakan pada penelitian adalah analisis univariat untuk mendeskripsikan masing-masing variabel yang diteliti, dan uji yang dibedakan adalah Uji T, yaitu uji beda dua mean dependent (paired sample), yaitu untuk menguji perbedaan penambahan berat badan sebelum dan sesudah diberikan edukasi.

\section{HASIL}

\section{Analisis Univariat}

Tabel 1. Distribusi Responden Berdasarkan Usia di RSUD Kota Tasikmalaya Agustus - September 2013. $(n=34)$

\begin{tabular}{cccccc}
\hline Variabel & Mean & Median & SD & Min - Mak & $95 \%$ Cl \\
\hline Usia & 49.65 & 50.50 & 10,433 & $25-64$ & $46.01-53.29$ \\
\hline
\end{tabular}


Berdasarkan tabel 1. terlihat bahwa rata-rata usia responden adalah 49.65 tahun. Usia responden paling muda 25 tahun sedangkan yang paling tua berusia 64 tahun.

Tabel 2. Distribusi Responden Berdasarkan Jenis Kelamin di RSUD Kota Tasikmalaya Agustus - September 2013. $(n=34)$

\begin{tabular}{llc}
\hline \multicolumn{1}{c}{ Variabel } & N & $\%$ \\
\hline Laki-Laki & 19 & 55.9 \\
Perempuan & 15 & 44.1 \\
\hline
\end{tabular}

Berdasarkan tabel 2. dapat diketahui bahwa pada sebagian besar responden berjenis kelamin laki-laki yaitu sebanyak 19 orang (55.9\%).

Tabel 3. Distribusi Responden Berdasarkan Tingkat Pendidikan di RSUD Kota Tasikmalaya Agustus - September 2013. $(n=34)$

\begin{tabular}{lcc}
\hline \multicolumn{1}{c}{ Variabel } & N & $\%$ \\
\hline SD & 0 & 0 \\
SMP & 1 & 2.9 \\
SMA & 22 & 64.7 \\
Diploma 3 & 2 & 5.9 \\
Sarjana & 9 & 26.5 \\
\hline
\end{tabular}

Berdasarkan tabel 3 dapat diketahui bahwa pada sebagian besar responden memiliki tingkat pendidikan SMA yaitu sebanyak 22 orang $(64.7 \%)$, tidak ada seorangpun responden dengan latar belakang pendidikan SD.

Tabel 4. Distribusi Rata-Rata Penambahan Berat Badan Sebelum dan Sesudah Edukasi di RSUD Kota Tasikmalaya Agustus - September 2013. $(n=34)$

\begin{tabular}{cccccc}
\hline Variabel & Mean & Median & SD & Min - Mak & $95 \% \mathbf{C l}$ \\
\hline $\begin{array}{l}\text { Penambahan BB } \\
\text { Sebelum Edukasi }\end{array}$ & 5.8 & 6.0 & 2.9 & $2-10$ & $5.2-6.4$ \\
$\begin{array}{l}\text { Penambahan BB } \\
\text { Sesudah Edukasi }\end{array}$ & 4.8 & 4.6 & 1.5 & $2.3-8.0$ & $4.1-5.4$ \\
\hline
\end{tabular}

Tabel 4. menunjukkan nilai rata-rata penambahan berat badan diantara dua waktu dialisis sebelum edukasi adalah sebesar 5.8. Hasil estimasi interval dapat disimpulkan bahwa 95\% diyakini bahwa rata-rata penambahan berat badan diantara dua waktu dialisis adalah diantara 5.2 - 6.4.

\section{Uji Normalitas}

Uji normalitas menggunakan uji normalitas kolmogorov-smirnov. Uji normalitas dilakukan untuk variabel numerik
Rata-rata penambahan berat badan diantara dua waktu dialisis sesudah edukasi adalah sebesar 4.8. Hasil estimasi interval dapat disimpulkan bahwa 95\% diyakini bahwa rata-rata penambahan berat badan diantara dua waktu dialisis adalah diantara $4.2-5.4$

usia, penambahan berat badan sebelum edukasi dan penambahan berat badan sesudah edukasi. Hasil uji normalitas digambarkan sebagai berikut : 
Tabel 5. Uji Normalitas Variabel Usia, Penambahan Berat Badan Sebelum dan Sesudah Edukasi di RSUD Kota Tasikmalaya Agustus - September 2013. $(n=34)$

\begin{tabular}{ll}
\hline \multicolumn{1}{c}{ Variabel } & $\boldsymbol{P}$ value \\
\hline Usia & 0.200 \\
Penambahan berat badan sebelum edukasi & 0.200 \\
Penambahan berat badan sesudah edukasi & 0.200 \\
\hline
\end{tabular}

Tabel 5 di atas menunjukan bahwa variabel usia terdistribusi normal dengan $p$ value 0.200 , penambahan berat badan sebelum edukasi terdistribusi normal dengan $p$ value 0.200 dan Penambahan berat badan sesudah edukasi terdistribusi normal dengan $p$ value 0.200 . Karena semua data terdistribusi dengan normal, maka analisis bivariat yang digunakan dalam penelitian ini adalah uji t dependen.

\section{Analisis Bivariat}

Tabel 6. Distribusi Rata-rata Penambahan Berat Badan Sebelum dan Sesudah Pemberian Edukasi di RSUD Kota Tasikmalaya Agustus - September 2013. $(n=34)$

\begin{tabular}{cccccc}
\hline $\begin{array}{c}\text { Penambahan } \\
\text { Berat Badan }\end{array}$ & Mean & SD & SE & P Value & N \\
\hline Sebelum & 5.83 & 1.73 & 0.29 & 0,0001 & 34 \\
Sesudah & 4.85 & 1.50 & 0.26 & & \\
\hline
\end{tabular}

Tabel 6. menunjukkan rata-rata penambahan berat badan sebelum edukasi yaitu 5.85, sedangkan rata-rata penambahan berat badan sesudah edukasi yaitu 4.85. Hasil uji statistik didapatkan $\mathrm{p}$

\section{PEMBAHASAN}

\section{Karakteristik Responden}

\section{a. Usia}

Hasil analisis univariat menunjukkan bahwa penderita Gagal Ginjal Kronik (GGK) yang menjalani hemodialisis di RSUD Kota Tasikmalaya rata-rata berumur 49.65 tahun dengan rentang usia $25-64$ tahun. Secara teori, penurunan fungsi ginjal mulai terjadi pada saat seseorang mulai memasuki usia 30 tahun dan pada usia 60 tahun fungsi ginjal menurun sampai $50 \%$ yang diakibatkan karena berkurangnya jumlah nefron dan tidak adanya kemampuan untuk regenerasi. Penurunan total aliran darah ginjal dan pengurangan dari ukuran dan jumlah glomerulus menyebabkan lansia mengalami penurunan GFR (Glomerular Filtration Rate), dan pada lanjut usia, value 0.000 , maka dapat disimpulkan terdapat perbedaan yang signifikan antara penambahan berat badan sebelum dan sesudah pemberian edukasi.

penyebab gagal ginjal kronik yang tersering adalah progressive renal sclerosis dan pielonefritis kronis.

Pada kenyataannya, usia bukanlah satu-satunya faktor resiko terjadinya penyakit gagal ginjal kronik. Obesitas, hipertensi dan diabetes mellitus merupakan faktor lain yang berperan dalam timbulnya penyakit gagal ginjal kronik. Gaya hidup modern yang dijalani oleh dewasa muda membuat kelompok usia tersebut mudah mengalami obesitas, hipertensi dan diabetes mellitus. Hasil penelitian di Amerika menunjukkan 19\% dewasa muda Amerika (usia 24-32 tahun) memiliki tekanan darah tinggi dan 3.7\% dari usia 20-44 tahun menderita penyakit DM (Clune \& Cane, 2011; Fill, 2011, Jungers et al, 1996). 
Menurut data US Renal Data System (2002) dalam Ignativius \& Workman (2006) diabetes dan hipertensi bertanggung jawab terhadap proporsi gagal ginjal kronik yang paling besar, terhitung secara berturut-turut sebesar $43,4 \%$ dan $25,5 \%$ dari total kasus. Beberapa penelitian lain juga membuktikan, penyakit hipertensi dan DM merupakan penyebab utama terjadinya gagal ginjal kronik (Smeltzer \& Bare, 2009).

Hipertensi yang melebihi $140 / 90$ $\mathrm{mmHg}$ akan menyebabkan kerusakan pada bagian korteks atau lapisan luar ginjal yang akan merangsang produksi hormon renin. Kelebihan hormon ini akan menstimulasi terjadinya peningkatan tekanan darah pada mereka yang mengalami kerusakan ginjal. Hipertensi bisa menimbulkan komplikasi ginjal dan penyakit ginjal bisa menyebabkan hipertensi. Di saat pembuluh darah menebal oleh timbunan lemak, tekanan darah pun meningkat. Akibatnya, aliran darah ke seluruh tubuh berkurang, termasuk aliran darah ke ginjal yang pada akhirnya menyebabkan komplikasi hipertensi berupa gagal ginjal.

Hipertensi dapat memperberat terjadinya kerusakan pada glomerulus dan pembuluh darah ginjal, dan karena itu, menjadi penyebab utama penyakit ginjal stadium akhir. Sebaliknya, kelainan fungsi ginjal dapat menyebabkan hipertensi. Pada beberapa keadaan, hubungan antara hipertensi dan penyakit ginjal dapat menimbulkan suatu lingkaran yang berbahaya: kerusakan ginjal primer dapat menimbulkan peningkatan tekanan darah, yang kemudian menyebabkan kerusaan ginjal lebih lanjut, lalu meningkatkan tekanan darah, dan seterusnya, sampai timbul penyakit ginjal stadium akhir (Guyton\& Hall, 2007).

Seperti halnya penderita hipertensi, penderita DM memiliki resiko sebesar 20\% hingga $40 \%$ untuk menderita penyakit renal. Sejumlah bukti menunjukkan bahwa segera sesudah terjadi diabetes, khususnya bila kadar glukosa darah meninggi, maka mekanisme filtrasi ginjal akan mengalami stress yang menyebabkan kebocoran protein darah ke dalam urin. Sebagai akibatnya, tekanan dalam pembuluh darah ginjal meningkat yang kemudian kenaikan tekanan tersebut akan menstimulasi terjadinya nefropati (Smeltzer and Bare, 2002).

\section{b. Jenis Kelamin}

Hasil penelitian pada tabel 4.2 menunjukkan bahwa jumlah penderita GGK yang menjalani hemodialisis di RSUD Kota Tasikmalaya yang berjenis kelamin laki-laki lebih banyak, yaitu 19 orang, sedangkan yang berjenis kelamin perempuan berjumlah 15 orang. Hasil penelitian ini sejalan dengan penelitian Junger $P$, et al (1996) yang menemukan bahwa insiden GGK tinggi pada laki-laki dibanding perempuan dalam setiap usia. Yamagata, et al (2007) juga menemukan bahwa peningkatan ureum kreatinin yang disebabkan oleh penurunan fungsi ginjal lebih banyak dialami oleh lakilaki dibandingkan perempuan. Demikian juga hasil penelitian Silbiger dan Neugarten (1995) yang menemukan bahwa penurunan fungsi ginjal pada laki-laki lebih cepat dibandingkan perempuan.

Laki-laki memiliki resiko lebih besar terhadap kejadian GGK dibandingkan perempuan karena kebiasaannya dalam merokok. Menurut Multiple Risk Factor Intervention Trial (MRFIT), merokok adalah salah satu faktor risiko utama yang dapat menyebabkan penyakit ginjal tahap akhir. Beberapa alasan yang mungkin dianggap bahwa merokok dapat membahayakan ginjal adalah: peningkatan tekanan darah dan denyut jantung, mengurangi aliran darah di ginjal, peningkatan produksi angiotensin II (hormon yang diproduksi dalam ginjal), mempersempit pembuluh darah di ginjal, merusak Arteriol (cabang arteri), dan pembentukan arteriosclerosis (penebalan dan pengerasan dari arteri ginjal).

Selain merokok, factor lain yang menyebabkan kaum laki-laki lebih beresiko terhadap penyakit GGK adalah karena adanya pengaruh sex hormone. Sex hormone diduga memediasi efek gender terhadap GGK, melalui interaksi dengan 
system rennin angiotensin aldosteron, modulasi sintesis nitric oxide dan menyebabkan penurunan kolagen. Sex hormone Androgen, diduga memiliki kontribusi terhadap berlangsungnya kehilangan fungsi ginjal pada laki-laki melalui stimulasi jalur apoptotic (apoptotic pathway), yaitu suatu tipe unik dari program kematian sel yang diaktivasi dalam penyakit GGK (Gandolvo, et al, 2004).

\section{c. Tingkat Pendidikan}

Hasil analisis univariat menunjukkan bahwa penderita Gagal Ginjal Kronik yang menjalani hemodialisis di RSUD Kota Tasikmalaya mayoritas memiliki riwayat pendidikan menengah, yaitu $64.7 \%$ berpendidikan SMA.

Azwar (1995) menyebutkan terdapat kaitan antara tingkat pendidikan terhadap perilaku positif yang menjadi dasar pengertian (pemahaman) dan perilaku dalam diri seorang individu. Hasil atau perubahan perilaku dengan cara ini membutuhkan waktu lama, tetapi perubahan yang dicapai akan bersifat langgeng karena didasari oleh kesadaran mereka sendiri. Tingkat pendidikan individu memberikan kesempatan yang lebih banyak terhadap diterimanya pengetahuan baru, termasuk informasi kesehatan.

Hasil penelitian Fored $\mathrm{CM}$, et al (2003) menemukan bahwa individu yang menempuh pendidikan selama 9 tahun atau kurang memiliki resiko $30 \%$ lebih tinggi untuk menderita penyakit ginjal kronik dibandingkan individu yang berpendidikan tinggi.

\section{Pengaruh Edukasi terhadap Penambahan Berat Badan Diantara Dua Waktu Dialisis}

Dari hasil penelitian pada tabel 4 menunjukkan nilai rata-rata penambahan berat badan diantara dua waktu dialisis sebelum dilakukan edukasi adalah sebesar 5.8 sedangkan rata-rata penambahan berat badan diantara dua waktu dialisis setelah dilakukan edukasi adalah sebesar 4.8. Hasil analisis lebih lanjut menunjukkan ada perbedaan yang signifikan rata-rata penambahan berat badan diantara dua waktu dialisis antara sebelum dan setelah dilakukan edukasi ( $p$ value $=0,0001$ ) .

Penambahan berat badan diantara dua waktu dialisis pada pasien GGK yang menjalani hemodialisis adalah hal yang tidak bisa dihindari, karena penurunan fungsi ginjal menyebabkan laju filtrasi glomerulus menurun sehingga tubuh gagal mengeluarkan cairan dari tubuh. Penambahan yang ringan masih dianggap aman, namun jika penambahan berat badan melebihi $4.8 \%$ dari berat kering pasien maka akan menimbulkan terjadinya berbagai komorbiditas, seperti hipertensi, hipotensi intradialilsis, gagal jantung kiri, peripheral edema, edema paru, asites, pleural effusion dan gagal jantung kongestif (Kopple dan Massry, 2004 dalam Pace, 2007; Henderson dalam Jaeger \& Mehta, 1999).

Ketidakpatuhan pasien dialisis terhadap pembatasan regimen terapi mereka, khususnya ketidakpatuhan terhadap pembatasan cairan sering menjadi penyebab terjadinya IDWG yang berlebihan (Barnet, et al, 2008; Oshvandi, et al, 2013). Terdapat bukti yang mengindikasikan bahwa pasien hemodialisis sering tidak mampu mematuhi diet dan membatasi konsumsi cairan mereka, sehingga perlu suatu upaya peningkatan pengetahuan self care melalui pemberian edukasi (Oshvandi, et al, 2013).

Wingard (2005) menyatakan edukasi pasien dapat memberikan kesempatan belajar bagi pasien dan keluarganya untuk meningkatkan pengetahuan, memperbaiki ketrampilan dan mengembangkan kemampuan kopingnya, dan tujuan dari edukasi pasien adalah terjadinya perubahan perilaku untuk jangka panjang. Hal ini dapat dicapai dengan cara memberikan pengetahuan yang memang dibutuhkan pasien sehingga pasien mampu membuat keputusan sendiri dan akhirnya akan memperbaiki outcome kesehatan individu tersebut.

Barnet AP, et al (2008) menemukan bahwa pemberian edukasi pada pasien hemodialisis dapat menurunkan penambahan berat badan diantara dua waktu dialysis dan pemberian edukasi 
secara signifikan dapat meningkatkan kepatuhan pasien terhadap pembatasan intake cairan. Demikian juga penelitian Baraz, et al (2006) dan Durose, et al (2004) yang menemukan adanya penurunan berat badan diantara dua waktu dialysis setelah pemberian edukasi. Penurunan ini terjadi karena pemberian edukasi dapat meningkatkan pengetahuan self care pasien sehingga pasien mampu merubah perilaku dan kebiasaannya dalam mematuhi diet dan membatasi cairan

Pada pasien hemodialisis pemberian edukasi self-care akan memberikan pengetahuan baru terhadap ranah kognitifnya, menambah pemahaman dan melatih kemampuan analisa terhadap keadaan kesehatannya dan menganalisa isi edukasi terhadap kondisi aslinya. Pasien juga memiliki sikap percaya kepada kemampuan dirinya dan memiliki nilai positif terhadap kehidupannya meskipun menjalani proses hemodialisis untuk seumur hidupnya. Ketrampilan psikomotor yang diperlukan pada pasien hemodialisis adalah

\section{KESIMPULAN}

Rata-rata umur responden adalah 49.65 tahun, dengan jenis kelamin laki-laki lebih banyak dari perempuan yaitu 19 orang (55.9\%), dan mayoritas responden memiliki latar belakang pendidikan SMA, yaitu sebanyak 22 orang $(64.7 \%)$. Terdapat perbedaan penambahan berat badan diantara dua waktu dialisis antara sebelum dan sesudah pemberian edukasi. Rata-rata penambahan berat badan diantara dua

\section{REFERENSI}

Ariawan, I. (2001). Besar Dan Metode Sampel Pada Penelitian Kesehatan. Jakarta : Jurusan Biostatistik dan Kependudukan Fakultas Kesehatan Masyarakat Universitas Indonesia.

Baraz S, Mohammad \& Boroumand. (2006). The effect of dietary regimen education on the laboratory variables and IDWG in hemodialysis patients. J Shahrekord Univ Med Sci. 2006;8(1): 20-7 kemampuan dalam menghitung cairan yang keluar dalam 24 jam dan mengatur jumlah cairan yang diperbolehkan untuk diasupnya. Kemampuan ini dapat muncul setelah pasien melakukan modeling terhadap sumber pengetahuannya. Model ini dapat berupa perawat sebagai nurse educator, suami/ istri atau pelaku rawat (caregiver) lainnya (Whitman, Graham, Gleit \& Boyd, 1992).

Penelitian lainnya yang sejalan dengan hasil penelitian ini adalah penelitian yang dilakukan oleh Dehaghani \& Shafaghi (2005) yang menemukan terdapat penurunan berat badan diantara dua waktu dialysis antara sebelum dan sesudah pemberian edukasi pada pasien hemodialisis. Lebih lanjut Sharp, et al (2005) menemukan bahwa setelah pemberian edukasi terdapat penurunan tekanan darah sistolik pada pasien yang menjalani hemodialisis, yang mana hal tersebut terjadi akibat dari adanya penurunan berat badan pada pasien setelah diberikan edukasi.

waktu dialisis menurun sesudah diberikan edukasi.

Rekomendasi dari penelitian ini perlu dilakukannya penelitian lebih lanjut tentang faktor-faktor yang mempengaruhi penambahan berat badan diantara dua waktu dialisis dan edukasi kepada pasien hemodialisis perlu dilakukan secara terprogram.

Black \& Hawks (2005) Medical surgical nursing clinical management for positive outcomes $7^{\text {th }}$ Edition. Elsevier Saunders. St Louis Missouri.

Barnett et al. (2008). Fluid compliance among patients having haemodialysis: can an educational programme make a difference? Journal of advance nursing. Oxford: Feb. Vol.61, Iss.3; pg.300

Clune \& Kane (2011). Study: 1 in 5 young adult suffers from hypertension. 
Dehaghani R., Abdollah, \& Shafaghi. (2005). The effect of diet education on blood pressure and weight of the hemodialysis in Kashan. Iranian Journal of Nursing and Midwifery Research [online], 10.4 (2005)

Durose, et al. (2004). Knowledge of dietary restrictions and the medical consequences of noncompliance by patients on haemodialysis are not predictive of dietary compliance. J Am Diet Assoc. 2004;104(1): 35-41

Gandolvo MT, et al. (2004). Gender and the progression of chronic Renal Disease: does apoptosis make the difference?

Ifudu et.al. (2002). Relation Between Interdialytic Weight Gain, Body Weight And Nutrition In Hemodialysis. American Journal of Nephrology; Jul/Aug 2002. Vol.22, no. 4, p363 (1999), pp. 392-403

Jaeger JQ, Mehta RL. (1999). Assesment of dry weight in hemodalysis an overview. J Am Soc Nephrol, Vol. 10

Johnson, J.Y. (2008). Texbook of medical surgical nursing. Elevent edition.Lippincot.

Jungers $P$, et al. (1995). Progression rate to end-stage renal failure in non-diabetic kidney disease: a multivariate analysis of determinant factors. Nephrol Dial Transplant 1995; 10: 1353-1360

Kallenbach, J.Z., Gutch, C.F., Stoner, M.H., Corea, A.L. ( 2005) Review of hemodialysis for nurse and dialysis peersonel. St. Lous Missouri : Mosby

McQuiston, CM., Webb, AA.(1995). Foundations of Nursing Theory. Thousand Oaks: Sage

Mollaoglu, M. (2009). Perceived Social Support, Anxiety, and Self-Care Among Patients Receiving Hemodialysis. Clinical Perspective. Dyalisis \& Transplantation. http://www3.interscience.wiley.com

NKUDIC. (2010). Kidney and urologic diseases statistics for the united states. http://kidney.niddk.nih.gov/kudiseases/p ubs/kustats/

National Kidney Foundation (2000). K/DOQI clinical Practice Guideline for chronic
Kidney disease: evaluations, classification, and stratification. http://www.kidneyorg/professionals/kdog i/guideline $\mathrm{ckd} / \mathrm{htm}$

Oshvandi, et al. (2013). Effect of small group educations on interdialytic weight gain and blood pressure in hemodialysis patients. Nursing \& midwifery studies. 2013. March; 1 (3): 128-32

Pace, RC.(2007). Fluid Management in Patient on Hemodialysis. Nephrology Nursing Journal. SeptemberOctober.Vol. 34, No. 5

Parsons, T.L., Toffelmire E.B., Valack C.E.( 2006). Exercise training during hemodialysis improves dialysis efficacy and physical performance. Arch Phys Med Rehabilitatio, 87 ,680-687. http://www.healthsystem.virginia.edu

Pernefri. (2003). Konsensus Dialisis Perhimpunan Nefrologi Indonesia. Jakarta

Price, S.A., \& Wilson M.W. (1995). Pathophysiology:Clinical Concepts of Disease Proces. Philadelphia: Mosby Year Book Inc.

Sharp J, Wild MR, Gumley AL, Deighan CJ. (2005). A cognitive behavioral group approach to enhance adherence to hemodialysis fluid restrictions: a randomized controlled trial. Am J Kidney Dis. 2005;45(6):1046-57. [Pubmed]

Silbiger SR, Neugarten J. (1995). The Impact of Gender on The Progression of Chronic Renal Disease. AM J Kidney Dis. 1995 Apr; 25 (4): 515-33

Suyono S \& Wapadji. (2001). Buku ajar penyakit dalam Jilid II Edisi ketiga. FKUI. Jakarta.

Thomas, N. (2002). Renal nursing (2nd edition). London United Kingdom: Elsevier Science

White R.B. (2004). Adherence to the Dialysis Prescription: Partnering with Patients for Improved Outcomes. Nephrology Nursing Journal. Pitman:Jul/Aug. Vol. 31, Iss. 4, p. 4325 (4 pp.)

Whitman, N.I., Graham, B. A., Gleit, C. J., \& Boyd, M. D. (1992). Teaching in nursing 
practice: A professional modl. Norwalk, CT: Appleton \& Lange

Wingard. (2005). Patient education and the nursing proces: meeting the patient's needs. Nephrol Nurs J. 2005 Mar-Apr, 32(2):211-4

Yamagata, et al. (2007). Risk Factor, for chronic kidney disease in a communitybased population: a 10-years follow-up study. Kidney International 71,159-166

Yetti K. (2001). Pengaturan Cairan Secara Mandiri Pada Pasien Yang Menjalani Hemodialisis. Jurnal Keperawatan Indonesia, Vol.V(2), Sept.2001 